\title{
Monitoring of Technogenic Destructions of Oil and Gas Facili- ties using 3D Laser Scanning
}

\author{
Olga Aleksandrovna Gubanova ${ }^{1 *}$, Vladimir Aleksandrovich Lovchikov $^{1}$, Aleksey Vladimirovich Mironchev ${ }^{1}$, Iliya \\ Danilovich Cheshko ${ }^{1}$, Alexander Sergeevich Krutolapov ${ }^{1}$ \\ ${ }^{1}$ Saint Petersburg University of State Fire Service of Emercom of Russia, Moskovskiy Avenue, 149, Saint Petersburg, 196105, Russia \\ *Corresponding author E-mail: gubanova.o.a@inbox.ru
}

\begin{abstract}
This article discusses application of 3D laser scanning aimed at assessment of consequences of destructions resulted from fires and other technogenic disasters of oil and gas facilities. Deformations of structures and equipment as a consequence of emergencies sometimes cannot be detected visually. It is required to apply modern instrumentation to determine deviations from designed parameters. In addition, after disasters it is required to determine the scope of loss and faults of equipment. Application of 3D laser scanning makes it possible to estimate both availability of buildings and equipment for further operation and the scope of destructions at complex engineering facilities of oil and gas industry. Laser scanning makes it possible to reduce significantly time required for examination and data processing in comparison with other measurement methods.
\end{abstract}

Keywords: 3D laser scanning; Deformation of structures; Hydrocarbon fire; Oil and gas facilities; Technogenic destructions.

\section{Introduction}

Technogenic emergencies are accompanied by failures of equipment and destruction of structures. The most frequent technogenic emergency at oil and gas facilities is fire. During fires building structures are exposed to high temperatures. At oil and gas facilities temperature during fire increases significantly faster and reaches higher levels than at burning of solid combustibles. In regulatory documents on fire safety, burning of oil and petroleum products is referred to as hydrocarbon fire [1]. The temperature during hydrocarbon fire can reach $1200^{\circ} \mathrm{C}$.

Thus, most fires at oil and gas facilities cause destructions or deformations of structures. Herewith, the deformations sometimes cannot be detected visually, specialized equipment is required for their evaluation. On the basis of the obtained results, decisions are adopted either on further operation and restoration of the structures, a part of facilities or on their complete replacement.

\section{Methods}

Downward movement of a building or its parts is referred to as settlement, upward movement - uplifting, and sideward movement - horizontal shift or displacement of a building [2]. Movements can occur along two planes: both vertical and horizontal.

Vertical displacement of buildings and single structures can be detected by the following procedures and their combinations:

- geometric leveling;

- trigonometric leveling;

- hydrostatic leveling;

- photogrammetry [3].

Absolute vertical displacements are those measured from reference point considered as initial, fixed. Relative displacements (settlement, uplifting) are vertical displacements with regard to a certain point of building.

Displacements of building parts are measured by the following procedures and their combinations:

- alignment survey;

- triangulation, trilateration, polygon surveys;

- certain directions, resections;

- photogrammetry.

Absolute horizontal displacements are determined with regard to reference point located outside of influence area of buildings and considered as fixed. Relative horizontal displacements are determined with regard to certain point of building.

Upon inclination of buildings it is necessary to take into account that in practice there exists inclination characterized by displacement of its vertical axis from plumb line and expressed in angular, linear or relative form, and inclination of foundation defined as displacement of its base from skyline and expressed in linear or relative form. This type of deformation is measured by the following methods or their combination if required [3]:

- alignment;

- coordination;

- measurement of angles or directions;

- photogrammetry;

- mechanical methods and using inclinometers and plumbs;

- levelling.

All aforementioned deformation types can be observed, measured, and analyzed using dedicated scanning devices which combine a set of monitoring methods of structure deformations as well as specialized programs for 3D simulation [4]. Laser scanning is an advanced simulation method applied in numerous industries $[5,6]$. 3D laser scanner creates point cloud of geometrical patterns of surface. These points can be used for extrapolation of subject shape. If color data are acquired in each point, then the colors on surface can also be determined and processed for subsequent presentation [7]. Laser scanners are similar to photo camera. They 
also have conic field of vision, hence, they can acquire data only for surfaces which were not covered. If a camera acquires information about color in the ranges of field of vision, then 3D scanner acquires information about distance to surfaces in the field of vision. The generated image describes distance to surface in each point [8].

Laser scanners determine distances by means of ranging laser. The beam passes the distance from emitter and, reflecting from the surface, returns to receiver. The distance passed by light pulse is levelled in time. Laser is used in order to emit light pulses and to measure time before the reflected light can be seen by detector. Since the beam speed (v) is known, it is required to determine the distance passed by light which is twice as large as that between scanner and surface. If $t$ is the time to and from the surface, then the distance is $(2 \mathrm{v} \cdot \mathrm{t}) / 2$, the time accuracy of laser beam transit depends on accuracy of time measurement $t$ [8].

Ranging laser determines only the distance of one point along vision direction. Therefore, scanner covers all field of vision for one point varying laser direction in preset range to scan various points. Direction of ranging scanner can be varied by rotation of main device or by rotating mirrors. The latter method is used more frequently because mirrors are much lighter, hence, they can be rotated faster and with higher accuracy. Measurement rate of 3D laser scanner varies from 100000 to 1000000 points per second [9] In most cases one scan will not provide complete model and it would be required to carry out scanning from several observation points. These images should be presented in common reference frame. This process of scan combination in order to obtain complete model is referred to as leveling or recording.

\section{Results}

Prior to scanning it is necessary to position marker targets (Fig. 1) so that upon subsequent scanning at least three targets would be visible in the field of view of point cloud common with other cloud [10]. If this condition is not satisfied, it will be impossible to combine these clouds at subsequent stage [11].

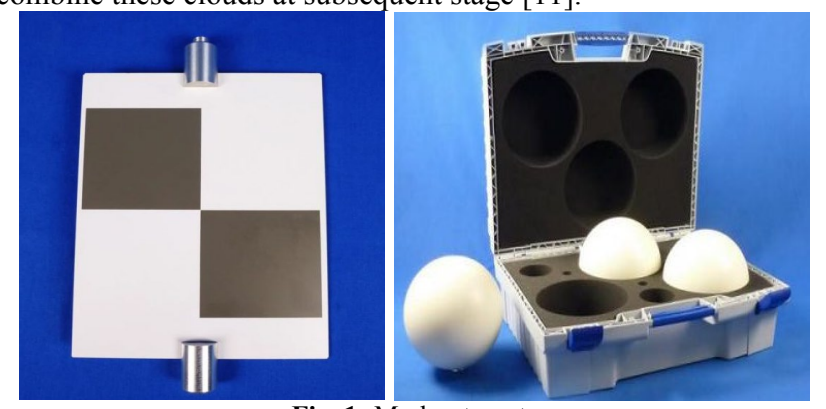

Fig. 1: Marker targets

In addition, while creating a point cloud it is required to locate optimally the device itself, and in order to obtain high quality cloud with minimum observation points, a set of conditions should be met:

- to locate the device so that beams would impinge at right angle to scanned subject;

- to consider for reflecting ability of scanned surfaces since the surfaces with high reflecting ability would produce error of coordinate measurements;

- to take into account geometry of structures in order to decrease blind zones (Fig. 2);

- to consider for illumination (at minimum illumination operation range is taken into account) [12].
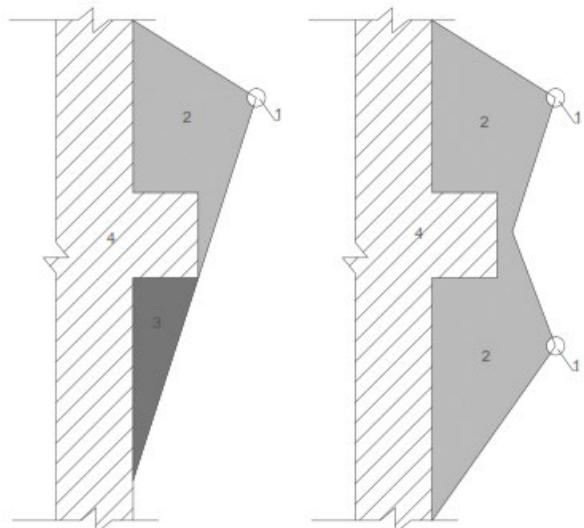

Fig. 2: Decrease in size of blind zones by increase in amount of observation points: 1 - observation point; 2 - visible scanner area; 3 - blind zone; 4 - scanned object.

Deformations of structures of oil and gas facilities were evaluated using a Trimble TX5 3D laser scanner [13]. Deformations were analyzed both inside buildings and of separate engineering supports and pipelines (Fig. 3). After survey completion the resulted files were exported to Autodesk ReCap. The acquired data can be exported to another software, such as FARO SCENE [14, 15].

The main purpose of such software is to combine files of scans, to remove noises, and to trim the resulted point cloud [16].

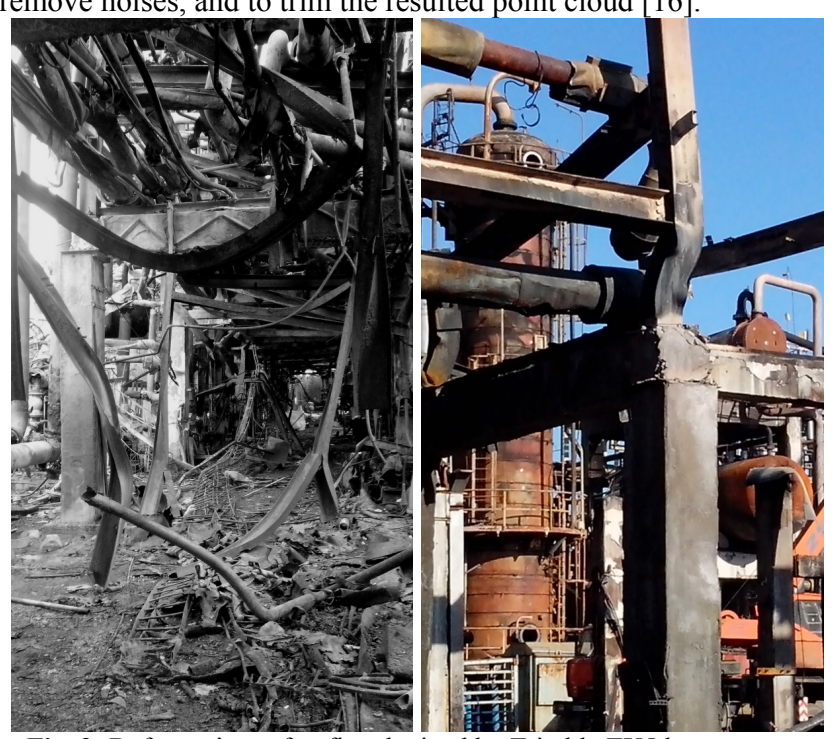

Fig. 3: Deformations after fire obtained by Trimble TX5 laser scanner

\section{Discussion}

After acquiring clouds from all observation points it is necessary to stitch all clouds into one using Trimble Real Works software.

Terrestrial laser scanning data were processed as follows:

1. Formation of unified point models for each engineering facility or building.

2. Creation of 3D polygonal models of facility.

3. Plotting of cross section using the model.

4. Computation of axis position of structures using the obtained cross sections.

5. Then the axis positions of structures were compared with designed data and deviations occurred during fire were determined. Clouds are stitched consecutively by matching common points in both stitched clouds. Herewith, at least three common points should be available, however, increase in number of common points not always improves processing quality since total error of deviation increases when one of target centers is determined wrongly. Hence, after stitching it is necessary to verify the devia- 
tion degree in mark registration log and to adjust fixing to these or those targets if necessary.

After registration of scans the data can be imported and processed using various software of $3 \mathrm{D}$ simulation. Later, possessing several files of scanning made at various times, it would be possible to compare them and to analyze variations of structure shapes and dimensions as well as critical displacements. Accuracy of measurements obtained by scanner is not higher than $3 \mathrm{~mm}$ per $100 \mathrm{~m}$. Another important advantage of 3D scanner is that when color scanning is not required the procedure can be performed without illumination without any loss in measuring accuracy.

An obvious advantage of laser scanning is that the obtained images can be converted into engineering drawings for preliminary specifications. Using scanner software at the first stage, point cloud is converted into 3D image of vector graphics. Then, using the $3 \mathrm{D}$ model, it is possible to obtain the required plans and cross sections suitable for processing in architecture engineering programs, such as AutoCAD and ArchiCAD. In fact, 3D laser scanning provides high level of automation in CAD systems [17], eliminates errors during bulk of not interrelated linear measurements and significantly reduces labor consumptions for examination of facility and development of graphic documentation [18]. This is highly important for oil and gas facilities since they are characterized by extensive pipeline network and high density of engineering equipment.

\section{Conclusion}

Observations of deformation of buildings and structures using 3D laser scanning systems make it possible to automate and to decrease the rate of assessment of structure state concerning existence of deformations and various damages, especially those of oil and gas facilities [19]. Visualization of scanning results reveals the level at which designs of buildings and structures provide their operability and reliability, as well as possibility to adopt simultaneously the measures against deformation or to eliminate their consequences [20]. Scanning measurements are especially important for valuation of consequences of technogenic disasters. Scanning results facilitate assessment of further operability of equipment and structures.

\section{References}

[1] EN 1363-2:1999 Fire resistance tests - Part 2: Alternative and additional procedures.

[2] Bol'shakov VD, Levchuk GP, Novak VE, et al. (1980), Spravochnoe rukovodstvo po inzhenerno-geodezicheskim rabotam [Guidebook on engineering and geodesic activities]. Moscow: Nedra.

[3] Domokeev AG (1989), Stroiteljnye materialy [Construction materials]. Manual for higher schools of civil engineering, 2-nd revised edition. Moscow: Vysshaya shkola.

[4] Alekseenko NN (2016), Primenenie tehnologii lazernogo skanirovaniya $\mathrm{v}$ razlichnyh otraslyakh i na razlichnyh ehtapah zhiznennogo tsikla ob'ektov [Laser scanning in various industries and at various stages of facility operation]. Vestnik MGSU 2, 62-73.

[5] Seredovich AV (2006), Postroenie tcifrovykh topograficheskikh planov ob'ektov neftedobychi s primeneniem nazemnogo lazernogo skanirovaniya [Plotting digital topographic maps of oil production facilities using terrestrial laser scanning]. Novosibirsk: Proceedings, “Geo-Sibir'-2006", April 24-28, Vol. 1, Ch. 2, 160-164

[6] Voroshilov AP \& Karachentsev YuA (2011), S'emka treschin pri nazemnom lazernom skanirovanii zdaniy i sooruzheniy [Crack surveying during terrestrial laser scanning of buildings]. Vestnik YUUrGU, Seriya: stroitel'stvo i arkhitektura 16(233).

[7] Bernardini F \& Holly E (2002), The 3D Model Acquisition Pipeline. Computer Graphics 21(2), 149-172.

[8] Seredovich VA, Komissarov AV, Komissarov DV \& Shirokova TA (2009), Nazemnoe lazernoe skanirovanie [Terrestrial laser scanning]. Novosibirsk: SGGA.

[9] Mizoguchi T, Koda Y, Iwaki I, Wakabayashi H, Kobayashi Y, Shirai K, Hara Y \& Lee H-S (2013), Quantitative scaling evaluation of concrete structures based on terrestrial laser scanning. Automation in Construction 35, 263-274.

[10] Altyntsev MA \& Antsifirov ES (2013), Issledovanie tochnost uravnivaniya dannyh mobiljnogo lazernogo skanirovaniya [Data equalization accuracy of mobile laser scanning]. Interekspo GeoSibir' 3.

[11] Batischeva OM \& Starchevojj IS (2011), Povyshenie kachestva proektirovaniya rekonstrukcii krupnomasshtabnyh i protyazhennyh ob'ektov na osnove metodov trehmernogo modelirovaniya [Quality improvement of retrofitting of large scale and extended facilities using 3D simulation]. Proceedings: Reliability and quality, International symposium, vol. 1, 279-281.

[12] Seredovich AV, Ivanov AV, Usikov AV, \& Miftahudinova OR (2011), Vy`polnenie obmerov stroitel'ny'kh konstruktcii` sredstvami nazemnogo lazernogo skanirovaniia pri obsledovanii zdanii` i sooruzhenii [Measurements of structures by terrestrial laser scanning upon examination of buildings]. Interekspo Geo-Sibir 2, 225-227.

[13] Trimble TX5 Laser scanner [Online resource]. Official web site of Trimble. Available online https://www.trimblegnss.ru/trimbletx5.html

[14] Kovach NS, Makarov AA, Moshev AA, Khlebutin SB (2015), Metody` lazernogo skanirovaniia: preimushchestva dlia krupny`kh infrastrukturny $\mathrm{kh}$ proektov (na primere rabot po modernizatcii Bai'kalo-Amurskoi` i Transsibirskoi` magistralei') [Laser scanning: advantages for large scale infrastructural projects (case study of Baikal-Amur and Trans-Siberian Railways)]. Inzhenerny ${ }^{\prime}$ izy skaniia 9, 22-25.

[15] Berényi A, Lovas T, Barsi Á \& Dunai L (2009), Potential of terrestrial laserscanning in load test measurements of bridges. Periodica Polytechnica Civil Engineering 53 (1), 25.

[16] Ovcharenko AV \& Medvedev OA (2015), Metodika operativnogo opredeleniia stepeni deformirovannosti sooruzhenii' na osnove $3 \mathrm{~d}$ skanirovaniia [Online determination of deformation rate of structures by 3D scanning]. Tekhnologii grazhdanskoi` bezopasnosti, 12(2(44)), 54-59.

[17] Russian standard GOST 23501.108-85. CAD systems. Classification and designation.

[18] Olen kov VD \& Popov DS (2012), Avtomatizatciia diagnostiki tekhnicheskogo sostoianiia zdanii' i sooruzhenii` $\mathrm{v}$ protcesse ikh e kspluatatcii [Automated diagnostics of technical state of buildings during their operation]. Vestneyk Iuzhno-Ural 'skogo gosudarstvennogo universiteta. Seriia: Stroitel'stvo i arhitektura, 17(276), 82-85.

[19] Kawashima K, Kanai S \& Date H (2014), As-built modeling of piping system from terrestrial laser-scanned point clouds using normalbased region growing. Journal of Computational Design and Engineering 1(1), 13-26.

[20] Eyre M, Foster P, Speake G, Coggan J (2017), Integration of Laser Scanning and Three-dimensional Models in the Legal Process Following an Industrial Accident. Safety and Health at Work 8(3), 306314. 